Saudi Journal of Oral and Dental Research

Abbreviated Key Title: Saudi J Oral Dent Res ISSN 2518-1300 (Print) IISSN 2518-1297 (Online) Scholars Middle East Publishers, Dubai, United Arab Emirates Journal homepage: http://scholarsmepub.com/sjodr/

\title{
DNA Damage Assessment in Buccal Epithelial Cells as Marker of Oral Cancer amongst Smokeless Tobacco (Khaini) and Alcohol Users
}

\author{
Sarim Ahmad ${ }^{1 *}$, Seema Sharma², Ahmed SS ${ }^{3}$, Yasar Hasan Siddique ${ }^{4}$, Uroosa Tabassum ${ }^{5}$, Smita Jyoti ${ }^{6}$, Shamim Ahmad \\ ${ }^{1,2}$ Department of Oral Pathology and Microbiology, Santosh Dental College, Ghaziabad India \\ ${ }^{3}$ Department of Oral and Maxillofacial Surgery, Dr. Z.A. Dental College, Aligarh Muslim University, Aligarh, India \\ ${ }^{4,6}$ Department of Zoology, Aligarh Muslim University, Aligarh, India \\ ${ }^{5}$ Dr. Z.A. Dental College, Aligarh Muslim University, Aligarh, India \\ ${ }^{7}$ Microbiology Section, Institute of Ophthalmology, JN Medical College, Faculty of Medicine, Aligarh Muslim University, Aligarh, India
}

\author{
DOI: $10.36348 /$ sjodr.2019.v04i11.005 $\quad$ | Received: 13.11.2019| Accepted: 20.11 .2019 | Published: 25.11 .2019 \\ *Corresponding author: Sarim Ahmad
}

\section{Abstract}

Introduction: Smokeless Tobacco contains considerable nicotine much more than is contained in smoking tobacco. Smokeless Tobacco contains 28 carcinogenic agents, including nitrites and alkylating agents causing oral cancer. Ethanol is the principal ingredient of alcoholic beverages Acetaldehyde, a metabolite of ethanol play an important role in ethanol toxicity by cross linking the DNA and thus leading to DNA damage. Comet Assay was performed to assess DNA damage among users of Smokeless Tobacco and Alcohol. Method: Buccal epithelial cells were taken from 25 users of Smokeless Tobacco (Khaini) 25 users of Alcohol, 25 users of Khaini and Alcohol and 25 control subjects and Comet Assay was performed to assess possible DNA damage. Result: Highest increase in the comet tail length implicated DNA damage in users of Smokeless Tobacco and Alcohol, both as compared to the control subjects. Conclusion: This study demonstrated DNA damage among users of Alcohol, Smokeless Tobacco leading to the development of oral cancer.

Keywords: Comet assay, Ethanol, Acetaldehyde, Buccal Epithelial Cells, DNA damage, Oral Cancer.

\begin{abstract}
Copyright @ 2019: This is an open-access article distributed under the terms of the Creative Commons Attribution license which permits unrestricted use, distribution, and reproduction in any medium for non-commercial use (NonCommercial, or CC-BY-NC) provided the original author and source are credited.
\end{abstract}

\section{INTRODUCTION}

Smokeless tobacco (ST) products have been consumed in varied amounts and their consumption lead to the development of oral cancer. Various forms of Smokeless Tobacco products have been used worldwide which are know by various names such as "Tombak" in Sudan, "Snus" in Sweden and "Khaini" in India with mass marketing of newer forms sold under different brand names. The term chewing tobacco is often associated with dipping tobacco such as split tobacco or moist snuff where users place a dip of tobacco between the lower or upper lip and gum by resting the dip on the inside lining of the mouth [1]. ST contains a greater amount of nicotine as compared to smoking tobacco [2]. ST although perceived as a safer alternative to smoking, contains 28 carcinogenic agents, including nitrites and alkylating agents [3]. Khaini, a form of Smokeless Tobacco and Alcohol are commonly known carcinogens in the development of oral cancer. Khaini is popularly used as an alternative to cigarette smoking in the Tamil Nadu region of Southern India. Tobacco, slaked lime paste and areca nut are the major components of Khaini [4].
ST had been classified as 'Carcinogenic to humans' by International Agency for Research Cancer [5]. Smokeless Tobacco products contain Tobaccospecific nitrosamines (TSNAs) which are associated with development of oral cancer in the consumers of these products [3] and [6]. Khaini has been reported to contain the highest levels of Tobacco specific Nnitrosamines (TSNAs) among the 32 Indian Smokeless Tobacco products such as N-nitrosonornicotine (NNN), 4-(methylnitrosamino)-1-(3-pyridyl)-1-butanone (NNK) and $\mathrm{N}$-nitrosoanabasine (NAB), as well as the volatile nitrosamines $\mathrm{N}$-nitrosodimethylamine and $\mathrm{N}$ nitrosodiethylamine formed by $\mathrm{N}$-nitrosation of nicotine [7]. ST damages the antioxidant defence mechanism increasing lipid peroxidation, DNA damage, cellular damage and oxidative stress level by generation of Reactive Oxygen Species [8].

Acetaldehyde is believed to be the carcinogenic agent behind alcohol-related oral cancers [9]. Consumption of Alcohol in larger quantities is associated with an increased risk of development of oropharyngeal cancer and cancer of gastrointestinal tract [10] and [9]. Chronic alcohol consumption and 
metabolism result in the production of endogenous DNA-damaging molecules such as reactive oxygen species including oxygen radicals, lipid peroxidation products [11].

Acetaldehyde, the first metabolite produced during alcohol degradation is responsible for the carcinogenic effect of ethanol on the upper respiratory tract due to its multiple mutagenic effects on DNA [12]. Various studies have shown that products of ethanol metabolism interact with DNA leading to disruption of the genomic function which can be fatal in nature. Nuclear and mitochondrial DNA strand-break formation was demonstrated at the hepatic level [13] and [14] as well as formation of DNA adducts [15] and [16]. Fewer studies have been conducted in brain where DNA strand breaks and DNA adduct formation have also been demonstrated [17] and [18]. A significant amount of DNA damage was observed in leucocytes of mice by long term administration of ethanol [11].

The "Comet Assay" also known as Single Cell Gel Electrophoresis (SCGE), is a unique and accurate technique for quantifying and analyzing DNA damage in individual cells which was originally developed by Östling and Johansson in 1984 [19] and [20]. The name of the assay is derived from the image which resembles a "comet" with a distinct head and tail. The cell with DNA damage appears in the form of "comet" while undamaged cell appears as a halo. The head is composed of intact DNA, while the tail consists of damaged (single-strand or double strand breaks) DNA. The Comet Assay (SCGE) has been used to detect DNA damage caused by double-strand breaks, single-strand breaks (SSB), alkali labile sites and oxidative base damage. [21] and [23]. The SCGE is also used to assess DNA repair by various cells in human body [24]. The extent of DNA liberated from the head of the comet is directly proportional to the amount of DNA damage [25]. Comet Assay can be applied to various types of cells like buccal epithelial cells and nasal cells that are highly susceptible to carcinogenic and mutagenic agents [26].

Various studies have been conducted to establish the synergistic effect of cigarette smoking and Alcohol consumption leading to oral cancer but the synergistic effect of Khaini (ST) and Alcohol have not been studied in the carcinogenesis of oral cavity nor have many studies demonstrated the association of these habits with demonstrable DNA damage.

During our study the main aim was to assess DNA damage in buccal epithelial cells of subjects having the habits of Khaini (Smokeless Tobacco) chewing and Alcohol consumption using Comet Assay (Single Cell Gel Electrophoresis) compared to the control subjects and to examine the association of DNA damage with these deleterious oral habits when consumed alone or in conjunction with each other.

\section{MATERIALS AND METHOD}

The study comprised of samples taken from 100 subjects (25 Khaini users, 25 Alcohol users, 25 users of Khaini and Alcohol in combination and 25 control subjects). The samples were taken from the subjects from Department of Oral and Maxillofacial Pathology \& Microbiology, Santosh Dental College, Ghaziabad and Dr. Ziauddin Ahmad Dental College \& Hospital, Aligarh Muslim University, Aligarh, UP. Complete history of oral habits was recorded from each subject before taking the sample. The samples were assessed for the extent of DNA damage using Comet Assay also known as Single Cell Gel Electrophoresis (SCGE).This study was approved by the ethical committee of Santosh Dental College, Ghaziabad, UP.

\section{MATERIALS}

\section{Chemicals Required}

1. Agarose-normal melting (Molecular Biology grade-MB)

2. Agarose-low melting (MB)

3. Sodium chloride $(\mathrm{NaCl})$ (Analytical Reagent gradeAR)

4. Potassium dihydrogen phosphate (AR)

5. Dimethyl sulphoxide (DMSO) (AR)

6. Trizma Hydrochloride (Tris) Base (AR)

7. Disodium Ethylene Diamine Tetra Acetic Acid (EDTA)-AR

8. Distilled water.

9. Sodium hydroxide (AR)

10. Tritron $X 100(\mathrm{MB})$

\section{Glasswares and other Consumables used}

1. Glass slides $(75 \times 25 \mathrm{~mm})-$ plain/frosted

2. Glass cover slips $(24 \times 60 \mathrm{~mm})$

3. Glass beakers $-100 \mathrm{ml}$ and $500 \mathrm{ml}$

4. Glass conical flask $-100 \mathrm{ml}, 500 \mathrm{ml}$ and $1000 \mathrm{ml}$

5. Glass measuring cylinder $-100 \mathrm{ml}$ and $1000 \mathrm{ml}$

6. Staining trough

7. Staining box (amber color)

8. Squeeze bottles $-100 \mathrm{ml}$ and $1000 \mathrm{ml}$

9. Glass marking pencil

10. Marker pen

11. Blunt forceps

12. Slide tray

13. Micropipette $10-100 \mu \mathrm{l}$ and $200-1000 \mu \mathrm{l}$

14. Micropipette tips 2-200 $\mu \mathrm{l}$ and $200-1000 \mu \mathrm{l}$

15. Micro-centrifuge tubes $1.5 \mathrm{ml}$

16. Pasture pipette

17. Slide storage box

18. Aluminum foil

\section{Instruments utilized}

1. Electronic weighing balance (minimum $0.001 \mathrm{~g}$ sensitivity)

2. Centrifuge

3. Water distillation unit

4. Microwave oven 
5. Refrigerator

6. Horizontal submarine gel electrophoresis system with power pack

7. Fluorescent microscope

8. Charge-coupled device (CCD) camera computer with image analysis software

9. Autoclave

10. Bottles for storing

\section{METHOD}

\section{Collection of buccal epithelial cells}

Buccal epithelial cells were collected from subjects by using a soft bristle tooth brush gently by scraping from the buccal mucosa. The brush was then swirled into a tube containing cold phosphate buffered saline (PBS) medium.

\section{Preparation of base slides}

1. Slides dipped in methanol were burned over a blue flame to remove the machine oil and dust.

2. While Normal Melting Point Agarose (NMPA) was hot, conventional slides were dipped up to one-third the frosted area and then gently removed. Underside of the slides was wiped clean to remove agarose and the slides were placed in a tray on a flat surface to dry. The slides were stored at room temperature.

\section{Cell isolation / treatment}

1. Buccal Cell isolation was performed in 1X Phosphate Buffer Solution and centrifuged at $2000 \mathrm{rpm}$ for 10 minutes followed with washing them three times.

2. $0.5 \%$ Low Melting Point Agarose (LMPA) solution was heated in the microwave and then $40 \mu \mathrm{L}$ of the sample and $60 \mu \mathrm{L}$ of $0.5 \%$ LMPA was mixed upto $100 \mu \mathrm{L}$ and then transferred to the slides. The tip of the plastic pipette was cut off in order to pass the cells through the tip adequately.

3. The mixed solution was gently placed on the slide and the cover slip was placed on the slide and then kept in fridge for $10 \mathrm{~min}$.

4. Coverslip was removed and third layer of $1 \%$ LMPA was placed on the slide.

5. The coverslip was placed again on the slide and kept in fridge for $10 \mathrm{~min}$.

6. The coverslip was gently removed and then slide was placed in coupling jar containing chilled lysing solution for 24 hours and the next day electrophoresis was performed.

\section{Electrophoresis of Frosted Slides}

1. The buffer reservoirs were filled with freshly made Electrophoresis Buffer solution $(\mathrm{pH}>13)$ until the liquid level completely covers the slides and bubbles should be avoided over the agarose solution.
2. The slides were kept in the alkaline electrophoresis buffer solution for 20 minutes (for unwinding of the DNA and the expression of alkali-labile damage).

3 . The power supply was turned on to 24 volts $(\sim 0.74$ $\mathrm{V} / \mathrm{cm})$ and the current was adjusted to 2 amperes and then the slides were left in the electrophoresis buffer solution for 45 minutes.

4. The power was then turned off and the slides were gently lifted from the buffer solution and placed on a drain tray. The slides were coated drop by drop with neutralization buffer solution and then left for 5 minutes. The slides were drained and this whole process was repeated two more times.

5. The slides were stained with $100 \mu \mathrm{L}$ of $1 \mathrm{X}$ ethidium bromide and left for 5 minutes and then dipped in chilled distilled water to remove excess stains. The whole procedure was carried out in a dark room and the slides were left for 24 hours for the next day to be viewed under the fluorescent microscope.

\section{Flourescent Microscopy}

For visualization of ethidium bromide-stained slides, fluorescent microscope equipped with an excitation filter of 515-560 nm with barrier filter of 590 $\mathrm{nm}$ and a magnification of $200 \mathrm{X}$ was used.

\section{Procedure for evaluation of DNA damage}

The DNA damage was estimated by measuring the length of the comet tail by using Comet Assay Score 1.5 Software (TriTek Corporation) and the visual scoring was done. In total, 40-50 randomly selected cells were analyzed per sample. Comets were selected without bias and represented the whole gel. Comets seen in edges, air bubbles and overlaps were rejected.

\section{STATISTICAL ANALYSIS}

The present study was conducted to assess the extent of DNA damage amongst Khaini and Alcohol users. Mean comet tail length of Khaini and Alcohol users was measured and compared in different groups. Mean tail length was compared between control subjects and different oral habit groups using t-test. All statistical analyses were done using $\operatorname{SPSS}^{\circledR}$ V8.2 statistical software package and Statistica Soft Inc.

\section{DISCUSSION}

The most commonly used cells in human studies were peripheral lymphocytes taken from venous or capillary blood. However, in order to cause minimal trauma to the subjects replacing lymphocytes with buccal epithelial cells was a better option so that the genotoxic and cytotoxic effects of deleterious habits like consumption of Smokeless Tobacco products and Alcohol in human subjects can be assessed more comprehensively. Moreover, as epithelial cells are the 
most common sites of malignant transformation, they are the most common type of cells which are selected for the assessment of DNA damage, cytotoxicity and genotoxicity. Exfoliated buccal epithelial cells have been used successfully to demonstrate the genotoxic effects of chewing of paan masala and tobacco smoking [27]. Investigators have shown that buccal epithelial cells are a potential source for targeting the mechanisms behind tobacco-related oral cancers [35]. Fewer studies have been carried out to demonstrate the genotoxic and cytotoxic effects of Alcohol on buccal epithelial cells. Buccal cells were collected by scraping of the buccal mucosa. This makes a buccal cell comet assay model an attractive and potentially useful tool for investigating in vitro and in vivo effects on DNA damage caused by the consumption of various Smokeless Tobacco (ST) products and Alcoholic beverages.

Smokeless Tobacco (ST) products contain a large number of carcinogens such as N-Nitrosamines $[28,1]$ and [33]. Epidemiological studies have been conducted to establish the significantly increased risk of oral cancer in users of various ST products [29] and [30]. Khaini or Smokeless Tobacco products cause genotoxicity that affects DNA repair pathways [31]. There are reports of the generation of Reactive Oxygen Species (ROS) by the aqueous extract of arecanut and catechu leading to the genotoxic damage in buccal epithelial cells [32] and [33]. ST consumption in its various forms like Khaini and consumption of Alcohol are associated with oral cancer, but no study till date has examined the association of these habits showing comparative DNA damage with respect to a particular disease and exposure to a variety of oral habits on one platform. The aim of the present study was to assess the DNA damage by collecting epithelial cells from the buccal mucosa among Khaini and Alcohol users.

The study by Mukherjee et al. [19] was performed on peripheral blood lymphocytes of humans; however we performed Comet assay on epithelial cells scraped from the buccal mucosa. The greater comet tail length associated with the consumption of Khaini in our study as compared to bidi, cigarette and pan users in the study of Mukherjee et al. [19] led us to infer that measuring the extent of DNA damage directly in oral epithelium would provide direct evidence of association of DNA damage in oral epithelium with these deleterious oral habits to develop an etiological explanation.
Winn et al. [34] conducted a study on 88 cases (38\%) and 138 control subjects (34\%) who have consumed at least 20 alcoholic beverages in their lifetimes. Most of the drinkers were smokers (69\%) and a relatively smaller proportion dipped snuff, the relative risks for oral and pharyngeal cancer increased with the amount of alcohol consumed but the effect was seen only among smokers and not with the snuff dippers (ST users) but with our study we demonstrated that a significant amount of DNA damage had occurred when Khaini, a form of ST product and Alcohol were consumed concomitantly. (Table 3, Fig.3). Thus, it can be in inferred that a significant amount of DNA damage can lead to oral or pharyngeal cancer among the combined users of Khaini and Alcohol. The synergistic effect of smoking and drinking on Esophageal Squamous Cell Carcinoma (ESCC) development was also observed in both males and females by Castellsagué et al. [35]. Blasiak et al. [8] studied the influence of ethanol and acetaldehyde on DNA in human lymphocytes, gastric mucosa and colonic mucosa by Comet Assay and they deduced that colonic mucosa cells showed the highest sensitivity of all cell types to ethanol than lymphocytes and gastric mucosa cells. Their results clearly indicated that ethanol and acetaldehyde can contribute to cancers of the digestive tract whereas in our study we studied the effect of Alcohol intake on buccal epithelial cells and showed an increased Comet Tail length indicating the risk of development of oral cancer.

Our study is one of the fewer studies to demonstrate DNA damage due to Alcohol use in buccal epithelial cells, earlier, Singh et al. [16] conducted an experiment which was the first one to demonstrate induction of DNA single-strand breaks after the consumption of Alcohol, but in rat brain cells and not buccal epithelial cells.

The individuals who are the consumers of ST products like Khaini and Alcohol have a greater prevalence in India and have a high cancer turnover potentiality and if detected early with the help of Comet Assay, then development of cancer can be prevented and treated successfully. The extent of DNA damage provides a potential platform to determine the cancer progression associated with the use of various ST products available in the market.

\section{RESULTS}

Table-1: Comet Tail Length in different groups-Males

\begin{tabular}{|c|c|c|c|}
\hline Group & $\mathbf{N}$ & Age $($ Mean \pm SE) & Comet tail length $($ Mean \pm SE) \\
\hline Khaini users & 14 & $36.00 \pm 2.1$ & $34.39 \pm 0.4^{*}$ \\
\hline Alcohol users & 17 & $39.05 \pm 1.5$ & $22.03 \pm 0.4^{*}$ \\
\hline Khaini + Alcohol users & 18 & $37.05 \pm 1.9$ & $40.85 \pm 0.5^{*}$ \\
\hline Controls & 14 & $34.00 \pm 2.1$ & $1.93 \pm 0.9$ \\
\hline
\end{tabular}




\section{OBSERVATION}

Table 1 shows the mean age and comet tail length for males divided into 4 groups-14 Khaini users, 17 Alcohol users, 18 Khaini + Alcohol users and 14 controls. The mean tail length in Khaini users was
$34.39 \pm 0.4$, in Alcohol users was $22.03 \pm 0.4$ and in Khaini + Alcohol users was $40.85 \pm 0.5$ which was significantly higher $(\mathrm{p}<0.05)$ compared to control subjects $(1.93 \pm 0.9)$. The highest tail length is seen in the group of Khaini + Alcohol users (Fig. 1).

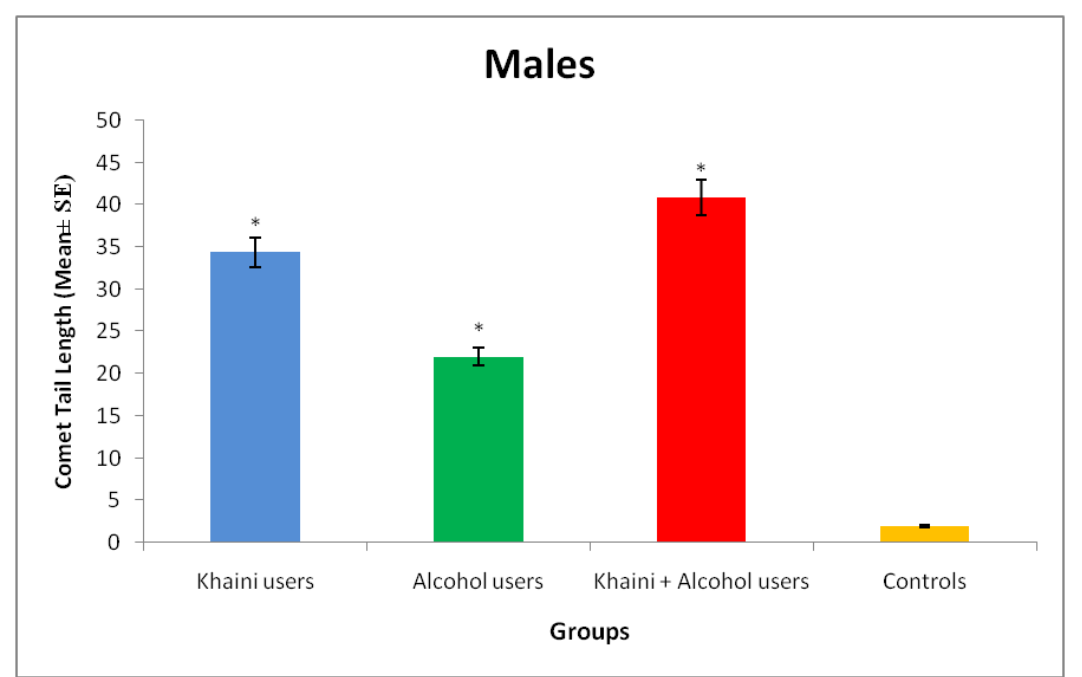

Fig-1: Mean Comet tail length among different groups (Males) [*Significant with respect to control, $\mathbf{p}<0.05$ ]

Table-2: Comet tail length in different groups-Females

\begin{tabular}{|c|c|c|c|}
\hline Group & $\mathbf{N}$ & Age $($ Mean \pm SE) & Comet tail length (Mean \pm SE) \\
\hline Khaini users & 11 & $32.27 \pm 1.8$ & $33.60 \pm 0.3^{*}$ \\
\hline Alcohol users & 8 & $30.50 \pm 1.8$ & $21.44 \pm 0.6^{*}$ \\
\hline Khaini + Alcohol users & 7 & $38.28 \pm 3.1$ & $41.84 \pm 0.5^{*}$ \\
\hline Controls & 11 & $33.82 \pm 2.1$ & $2.02 \pm 0.1$ \\
\hline
\end{tabular}

\section{OBSERVATION}

The mean age and comet tail length for females who were the users of Khaini (11 users), Alcohol (8 users) and Khaini + Alcohol users (7 users) and 11 control subjects is shown in Table 2.The mean tail length in Khaini users was $33.6 \pm 0.3$, in alcohol users was $21.44 \pm 0.6$ and in Khaini + Alcohol users was $41.84 \pm 0.5$ was significantly higher $(\mathrm{p}<0.05)$ as compared to control subjects whose mean tail length was $2.02 \pm 0.1$. From this table we can conclude that the highest comet tail length was observed in the group of Khaini + Alcohol users (Fig. 2).

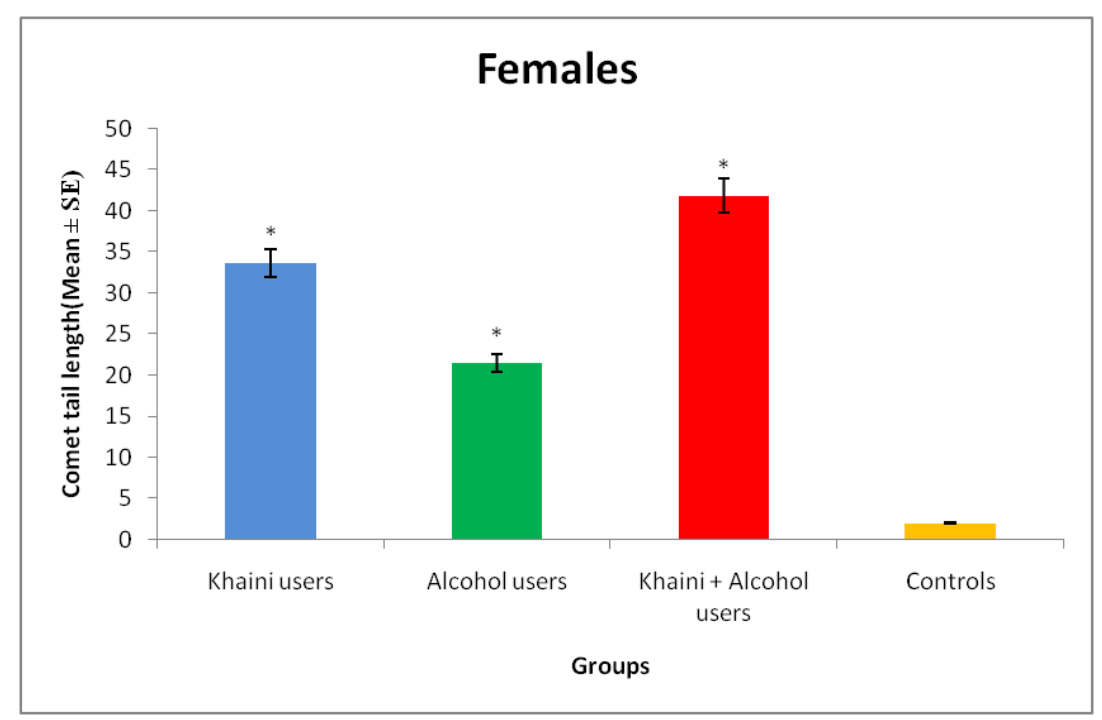

Fig-2: Mean comet tail length among different groups (Females) [*Significant with respect to control, $\mathbf{p}<0.05$ ] 
Table-3: Comet tail length in different groups-Males and Females combined

\begin{tabular}{|c|c|c|c|}
\hline Group & $\mathbf{N}$ & Age $($ Mean \pm SE) & Comet tail length (Mean \pm SE) \\
\hline Khaini users & 25 & $34.56 \pm 1.5$ & $34.04 \pm 1.2^{*}$ \\
\hline Alcohol users & 25 & $36.32 \pm 1.4$ & $21.84 \pm 0.4^{*}$ \\
\hline Khaini + Alcohol users & 25 & $37.40 \pm 1.6$ & $41.13 \pm 0.4^{*}$ \\
\hline Controls & 25 & $33.92 \pm 1.5$ & $1.97 \pm 0.1$ \\
\hline
\end{tabular}

\section{OBSERVATION}

The mean of the age and comet tail length for both Males as well as Females combined which were 25 in number for each group are shown in Table 3 . The mean tail length in Khaini users observed was $34.04 \pm$
1.2, in Alcohol users was $21.84 \pm 0.4$ and in Khaini + Alcohol users was $41.13 \pm 0.4$ was significantly higher $(\mathrm{p}<0.05)$ as compared to control subjects whose mean tail length was $1.97 \pm 0.1$ (Fig. 3).

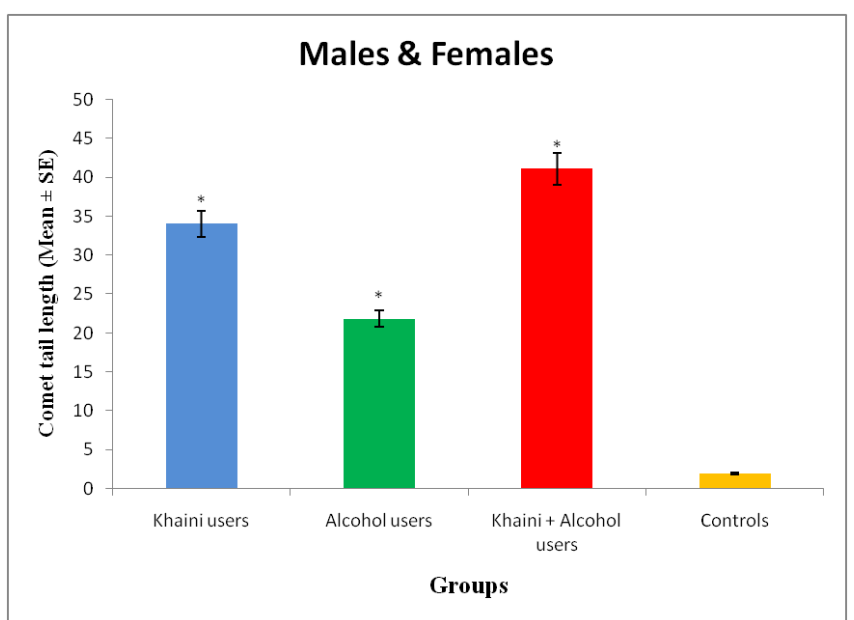

Fig-3: Mean Comet tail length among different groups (Males and Females) [*Significant with respect to control, $\mathbf{p}<0.05]$

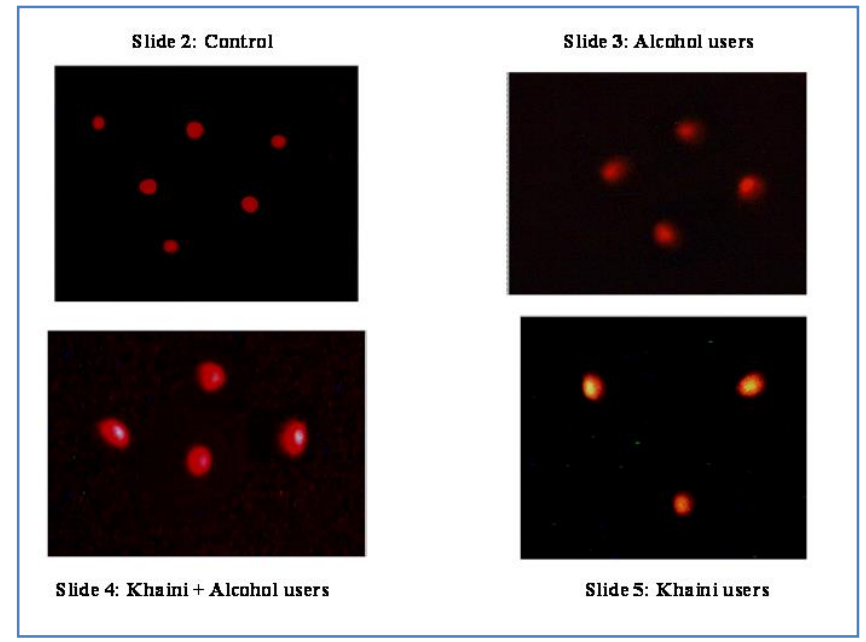

Fig-4

\section{ACKNOWLEDGEMENTS}

This research work was performed in joint collaboration of Santosh Dental College, Santosh University, and Ghaziabad, UP, India and Dr. Ziauddin Ahmad Dental College, Aligarh Muslim University, Aligarh, UP, India and Department of Zoology, Aligarh Muslim University, Aligarh, India and was self-funded.

\section{DISCLOSURE}

Dr.Sarim, Seema Sharma, S.S. Ahmed,Yasir Hasan, Smita Jyoti, Shamim Ahmad have nothing to disclose.

\section{CONFLICT OF INTERESTS}


The authors have no competing financial

interests to declare.

\section{REFERENCES}

1. Hoffmann, H., \& Speit, G. (2005). Assessment of DNA damage in peripheral blood of heavy smokers with the comet assay and the micronucleus test. Mutation Research/Genetic Toxicology And Environmental Mutagenesis, 581(1-2), 105-114.

2. Sardas, S., Cimen, B., Karsli, S., Yurdun, T., \& Donbak, L. (2009). Comparison of genotoxic effect between smokeless tobacco (Maras powder) users and cigarette smokers by the alkaline comet assay. Human \& Experimental Toxicology, 28(4), 214-219.

3. Khanna, A., Gautam, D., \& Mukherjee, P. (2012). Genotoxic effects of tobacco chewing. Toxicology International, 19(3), 322.

4. Garg, A., Chaturvedi, P., Mishra, A., \& Datta, S. (2015). A review on harmful effects of pan masala. Indian Journal Of Cancer, 52(4), 663.

5. Nair, U. (2004). Alert for an epidemic of oral cancer due to use of the betel quid substitutes gutkha and pan masala: a review of agents and causative mechanisms. Mutagenesis, 19(4), 251262.

6. Rohatgi, N., Kaur, J., Srivastava, A., \& Ralhan, R. (2005). Smokeless tobacco (khaini) extracts modulate gene expression in epithelial cell culture from an oral hyperplasia. Oral Oncology, 41(8), 806-820.

7. Giovino, G. A., Mirza, S. A., Samet, J. M., Gupta, P. C., Jarvis, M. J., Bhala, N., ... \& Palipudi, K. M. (2012). Tobacco use in 3 billion individuals from 16 countries: an analysis of nationally representative cross-sectional household surveys. The Lancet, 380(9842), 668-679.

8. Blasiak, J., Trzeciak, A., Malecka-Panas, E., Drzewoski, J., \& Wojewódzka, M. (2000). In vitro genotoxicity of ethanol and acetaldehyde in human lymphocytes and the gastrointestinal tract mucosa cells. Toxicology In Vitro, 14(4), 287-295.

9. Kido, R., Sato, I., \& Tsuda, S. (2006). Detection of in vivo DNA Damage Induced by Ethanol in Multiple Organs of Pregnant Mice Using the Alkaline Single Cell Gel Electrophoresis (Comet) Assay. Journal of Veterinary Medical Science, 68(1), 41-47.

10. Guo L, Yang JY, Wu CF. Oxidative DNA damage induced by ethanol in mouse peripheral leucocytes. Basic \& clinical pharmacology \& toxicology. 2008;103(3):222-227.

11. Seitz, H., \& Stickel, F. (2007). Molecular mechanisms of alcohol-mediated carcinogenesis. Nature Reviews Cancer, 7(8), 599612.

12. Mansouri, A., Gaou, I., de Kerguenec, C., Amsellem, S., Haouzi, D., Berson, A., \& Fromenty, B. (1999). An alcoholic binge causes massive degradation of hepatic mitochondrial DNA in mice. Gastroenterology, 117(1), 181-190.

13. Navasumrit, P. (2000). Ethanol-induced free radicals and hepatic DNA strand breaks are prevented in vivo by antioxidants: effects of acute and chronic ethanol exposure. Carcinogenesis, 21(1), 93-99.

14. Brooks, P. (1997). DNA Damage, DNA Repair, and Alcohol Toxicity--A Review. Alcoholism: Clinical \& Experimental Research, 21(6), 1073.

15. Navasumrit, P., Ward, T., O’Connor, P., Nair, J., Frank, N., \& Bartsch, H. (2001). Ethanol enhances the formation of endogenously and exogenously derived adducts in rat hepatic DNA. Mutation Research/Fundamental and Molecular Mechanisms of Mutagenesis, 479(1-2), 81-94.

16. Singh, N. P., Lai, H., \& Khan, A. (1995). Ethanolinduced single-strand DNA breaks in rat brain cells. Mutation Research/Genetic Toxicology, 345(3-4), 191-196.

17. Vaudry, D., Rousselle, C., Basille, M., FalluelMorel, A., Pamantung, T. F., Fontaine, M., Gonzalez, B. J. (2002). Pituitary adenylate cyclaseactivating polypeptide protects rat cerebellar granule neurons against ethanol-induced apoptotic cell death. Proceedings of the National Academy of Sciences, 99(9), 6398-6403.

18. Ostling, O., \& Johanson, K. (1984). Microelectrophoretic study of radiation-induced DNA damages in individual mammalian cells. Biochemical and Biophysical Research Communications, 123(1), 291-298.

19. Chaudhuri, K., Mukherjee, S., \& Ray, J. (2011). Evaluation of DNA damage in oral precancerous and squamous cell carcinoma patients by single cell gel electrophoresis. Indian Journal of Dental Research, 22(5), 735.

20. Fairbairn, D. W., Olive, P. L., \& Oneill, K. L. (1995). The comet assay: a comprehensive review. Mutation Research/Reviews in Genetic Toxicology, 339(1), 37-59.

21. Rojas, E., Lopez, M., \& Valverde, M. (1999). Single cell gel electrophoresis assay: methodology and applications. Journal of Chromatography $B$ : Biomedical Sciences and Applications, 722(1-2), 225-254.

22. Anderson, D., Yu, T.-W., \& Mcgregor, D. B. (1998). Comet assay responses as indicators of carcinogen exposure. Mutagenesis, 13(6), 539-555.

23. Jyoti, S., Khan, S., Naz, F., Rahul, Ali, F., \& Siddique, Y. H. (2013). Assessment of DNA damage by panmasala, gutkha chewing and smoking in buccal epithelial cells using alkaline single cell gel electrophoresis (SCGE). Egyptian Journal of Medical Human Genetics, 14(4), 391394.

24. Brennan, P. (2007). Comment on 'Enhanced lipid peroxidation and nitric oxide products with deranged anti-oxidant status in patients with head and neck squamous cell carcinoma' [Rasheed $\mathrm{MH}$, 
Beevi SS, Geetha A. Oral Oncology 2007;43:3338]. Oral Oncology, 43(4), 416-417.

25. Kawanishi, S., Hiraku, Y., Pinlaor, S., \& Ma, N. (2006). Oxidative and nitrative DNA damage in animals and patients with inflammatory diseases in relation to inflammation-related carcinogenesis. Biological Chemistry, 387(4).

26. Jyoti, S., Naz, F., Rahul, Khan, S., Ali, F., Fatima, A., Siddique, Y. H. (2014). Detection of aneugenicity and clastogenicity in buccal epithelial cells of pan masala and gutkha users by pancentromeric FISH analysis. Mutagenesis, 30(2), 263-267.

27. Hoffmann, D., \& Djordjevic, M. (1997). Chemical Composition and Carcinogenicity of Smokeless Tobacco. Advances in Dental Research,11(3), 322329.

28. Critchley, J. A. (2003). Health effects associated with smokeless tobacco: A systematic review. Thorax, 58(5), 435-443.

29. Warnakulasuriya, K. A., \& Ralhan, R. (2007). Clinical, pathological, cellular and molecular lesions caused by oral smokeless tobacco - a review. Journal of Oral Pathology \& Medicine,36(2), 63-77.

30. Pershagen, G. (1996). Smokeless tobacco. British Medical Bulletin,52(1), 50-57.
31. Zhao, K., Luo, G., Giannelli, S., \& Szeto, H. H. (2005). Mitochondria-targeted peptide prevents mitochondrial depolarization and apoptosis induced by tert-butyl hydroperoxide in neuronal cell lines. Biochemical Pharmacology,70(12), 17961806.

32. Warnakulasuriya, S. (2009). Significant oral cancer risk associated with low socioeconomic status. Evidence-Based Dentistry, 10(1), 4-5.

33. Winn, D. M., Blot, W. J., Shy, C. M., Pickle, L. W., Toledo, A., \& Fraumeni, J. F. (1981). Snuff Dipping and Oral Cancer among Women in the Southern United States. New England Journal of Medicine,304(13), 745-749.

34. Castellsagu, X., MuOz, N., Stefani, E. D., Victora, C. G., Castelletto, R., Roln, P. A., \& Quintana, M. J. (1999). Independent and joint effects of tobacco smoking and alcohol drinking on the risk of esophageal cancer in men and women. International Journal of Cancer, 82(5), 657-664.

35. Spivack, S. D., Hurteau, G. J., Jain, R., Kumar, S. V., Aldous, K. M., Gierthy, J. F., \& Kaminsky, L. S. (2004). Gene-Environment Interaction Signatures by Quantitative mRNA Profiling in Exfoliated Buccal Mucosal Cells. Cancer Research, 64(18), 6805-6813. 